\title{
JEJAK AUSTRONESIA PADA MASYARAKAT DAYAK MERATUS DI KABUPATEN KOTABARU KECAMATAN HAMPANG
}

\section{THE AUSTRONESIAN TRACE ON THE DAYAK MERATUS PEOPLE IN KOTABARU, HAMPANG DISTRICT}

\author{
Rissari Yayuk \\ Balai Bahasa Provinsi Kalimantan Selatan \\ Jln. A. Yani. Km. 32,2. Lok Tabat. Banjarbaru. Kalimantan Selatan \\ Email: yrissariyayuk@yahoo.co.id
}

DOI: $10.36424 / j p s b . v 5 i 2.34$

\begin{abstract}
Naskah Diterima:9 April 2019 Naskah Direvisi:23 Oktober 2019
Naskah Disetujui: 23 Oktober 2019
\end{abstract}

\begin{abstract}
Abstrak
Masyarakat Dayak Meratus di Kecamatan Hampang Kabupaten Kotabaru, termasuk rumpun Austronesia. Perlu dibuktikan adanya pewarisan yang ditinggalkan oleh Proto Austronesia ini pada masyarakat tersebut. Tujuan penelitian mendeskripsikan wujud jejak budaya penutur Austronesia pada masyarakat Dayak Meratus, Kecamatan Hampang, Kabupaten Kotabaru. Metode yang digunakan adalah deskriptif kualitatif dan kuantitatif. Hasil penelitian membuktikan adanya pewarisan kehidupan sosial budaya dan bahasa. Kehidupan sosial budaya masyarakat Dayak Meratus Kecamatan Hampang memiliki kemiripan bentuk maupun konsep dengan Austronesia, meliputi peralatan hidup, hunian, pemenuhan kebutuhan hidup, pakaian asesoris, dan kepercayaan. Sementara itu, dari perbandingan kosakata kedua penutur menggambarkan adanya hubungan kekerabatan yang diwariskan sebesar 48\%. Atau dengan kata lain bahasa Dayak Meratus Kecamatan Hampang, Provinsi Kalimantan Selatan berada dalam kategori keluarga bahasa dengan Proto Austronesia. Dapat diesimpulan wujud jejak penutur Autronesia masa silam pada masyarakat Dayak Meratus Kecamatan Hampang ini dibuktikan dengan unsur nonlinguistik dan linguistik.
\end{abstract}

Kata kunci: Austronesia, Dayak Meratus,Antropolinguistik

\section{Abstract}

Meratus Dayak Community in Kotabaru Regency, Hampang Regency is inluded into an Austronesian family. It is important to prove the existence of the trace left by Proto Austronesian in these communities. The objective of this study is to describe the cultural traces left by Austronesian speaker in the Dayak Meratus community, Hampang District, Kotabaru Regency. The research uses qualitative and quantitative approaches. Based on the results, 
the study proves that there are socio-cultural and linguistic heritage. The socio-cultural life of the Dayak Meratus community in Hampang Subdistrict has similarities in form and concept with Austronesian, including living equipment, housing, fulfillment of life needs, clothing accessories, and belief. Meanwhile, the comparison of two vocabularies from both speakers illustrates the inherited family relation by $48 \%$. Or in other words Dayak Meratus language of Hampang District, Kotabaru Regency is in the language family category with Proto Austronesian. The trace of Austronesian language of the past time in Dayak Meratus People in Hampang District is proven by nonlinguistic and linguistic elements.

Keywords: Austronesian, Dayak Meratus, Anthropolinguistics

\section{PENDAHULUAN}

Kecamatan Hampang terletak di Kabupaten Kotabaru, kecamatan ini berada di kaki Pegunungan Meratus terdiri atas dataran tinggi, lembah, dan perbukitan kapur. Masyarakat yang berada di wilayah ini disebut dengan Dayak Meratus. Temuan dari Balai Arkeologi Banjarmasin yang menemukan jejak Penutur Austronesia di Kecamatan Hampang. (Sugiyanto 2015: 36) menyebutkan hasil survei arkeologi yang dilakukan Hartatik dkk. Menemukan jejak Penutur Austronesia dalam situs gua berlukis di jajaran pegunungan karst di Desa Hampang, Kecamatan Hampang, Kabupaten Kotabaru. Sebuah gua yang dikeramatkan masyarakat karena adanya gambar-gambar berwarna hitam pada langit-langitnya. Gambar tersebut bermotif perahu, binatang berkaki empat, dan matahari. Sugiyanto (2014:60) menyebutkan Situs Liang Batu Batulis di Kecamatan Hampang erat kaitannya dengan kepercayaan masyarakat (tradisi pemujaan).

Penutur Austronesia tersebar hingga ke wilayah Borneo/Kalimantan. (Khusna 2015: 8). Bangsa Austronesia ini , awalnya menduduki daerah pesisir pantai Kalimantan. Kedatangan bangsa Melayu dari semenanjung Sumatera dan Malaka yang ditambah dengan kedatangan Bugis, Makasar, dan Jawa memaksa mereka mundur ke pedalaman Kalimantan. Hal ini menyebabkan suku Dayak hidup terpencar dan menyebar di berbagai daerah hingga berbagai sub-etnis. (Faidi, 2015:9 
Menarik sekali apabila peneliti dapat membuktikan masih ada atau tidaknya jejak budaya penutur Austronesia. Wujud jejak Penutur Austronesia dalam kehidupan masyarakat Dayak Meratus di Kecamatan Hampang yang kaya akan sumber hayatinya ini kemungkinan besar dapat dilihat berdasarkan budaya keseharian mereka dalam bentuk materi maupun konsep. Akan tetapi, untuk membuktikan lebih lanjut apakah masih ada pewarisan budaya dari nenek moyang mereka ini yang melekat, baik yang berwujud materi maupun konsep dalam kehidupan sehari-hari, perlu dilakukan penelitian yang lebih dalam. Mengingat pula era globalisasi juga sudah menghampiri kecamatan ini. Masa kedatangan Penutur Austronesia pun sudah berlangsung ribuan tahun yang lalu. Berdasarkan paparan di atas. Masalah yang dikaji meliputi bagaimana wujud jejak budaya penutur Austronesia pada masyarakat Dayak Meratus, Kecamatan Hampang, Kabupaten Kotabaru. Tujuan penelitian mendeskripsikan wujud jejak budaya penutur Austronesia pada masyarakat Dayak Meratus, Kecamatan Hampang, Kabupaten Kotabaru.

Khusna (2015) membuat artikel Migrasi Austronesia di Asia Tenggara. Khusna memaparkan tentang penutur Autronesia yang tersebar di Indonesia, Malaysia, Filipina, Singapura, Brunei, serta etnis tertentu di Taiwan, Vietnam, Kamboja, Birma, Timur Leste, dan etnis di pantai utara Papua. Suroto (2016) dengan Budaya Austronesia di Kawasan Danau Sentani. Suroto mengemukakan bahwa persebaran artefak gerabah dan bahasa menunjukkan Penutur Austronesia lebih banyak bermukim, beraktivitas, dan berinteraksi dengan penduduk asli Papua pesisir.

Kedua artikel penelitian sebelumnya ini memiliki persamaan objek kajian yaitu membahas mengenai budaya Austronesia. Namun, perbedaannya adalah peneliti tidak membahas tentang migrasi Austronesia ke berbagai wilayah melalui artefak sebagaimana yang dikaji tiga peneliti di atas. Peneliti mengungkapkan tentang jejak penutur Austronesia pada masyarakat Dayak Meratus di Kecamatan Hampang melalui budaya keseharian termasuk bahasanya. Sunarningsih 2015:4) menyatakan 
karakteristik merupakan ciri khusus. Jika digabung dengan budaya nenek moyang maka yang dianggap ciri khusus tersebut adalah sesuatu yang melekat dan terdapat pada budaya nenek moyang.

Budaya kesaharian yang dimaksud dalam penelitian ini meliputi aspek peralatan hidup, hunian, cara pemenuhan kebutuhan hidup atau mata pencaharian, pakaian dan asesoris serta bahasa Dayak Meratus Kecamatan Hampang. Hasil yang dipeoleh dari budaya keseharian ini akan dianalisis persamaan atau kemiripan dengan sosial budaya Proto Austronesia berdasarkan teori yang dikemukakan oleh banyak pakar selama ini. Khusna (2015:13) menyatakan bahwa kebudayaan Austronesia berkembang, beranak-pinak, dan mendarah daging di wilayah koloninya. Mata pencaharian dan alat kehidupan hasil kebudayaann-Austronesia memberikan hasil yang nyata hingga kini. Selain tinggalan bendawinya, kajian linguistik bisa dijadikan rujukan untuk menarik akar Penutur Austronesia.

Koentjaraningrat dalam (Hartatik, 2014:30) menyatakan bahwa proses pergeseran masyarakat dan kebudayaan tidak lepas dari konsep dinamika sosial yang meliputi proses belajar, evolusi kebudayaan, dan proses penyebaran kebudayaan. Prasetyo (2015:182) menyatakan bahwa unsur teknologi penutur Austronesia dapat dicirikan seperti bercocok tanam padi, ani-ani, membuat tembikar, berumah panggung dengan denah segiempat, mengayau, membuat minuman dari beras, memelihara babi dan kerbau untuk upacara, mendirikan megalitik, dan memperkenalkan perahu cadik. Khusna (2015:23) menyebutkan, rumah penutur Austronesia dibuat model panggung dengan ditopang pasak-pasak kayu, dengan tujuan untuk menghindari banjir, hewan buas, sehingga aman di lingkungan terbuka yang saat itu masih liar. Suroto (2016:122) menyatakan kebudayaan Penutur Austronesia mengenal domistikasi ayam, anjing, dan babi. Peralatan yang mereka kenal adalah manik-manik, mata kail, gelang tangan, dan terompet. Organisasi kemasyarakatan terstruktur dalam sistem hierarki, para pemimpinnya dijabat secara turun temurun. Suroto (2010:55) menyatakan bahwa beberapa pendapat dari para ahli menyebutkan bahwa ciri khas budaya Austronesia 
meliputi mengunyah sirih, membuat tato, rumah panggung, pembuatan minuman beralkohol dari aren.

Pendapat-pendapat di atas mengemukakan tentang materi budaya dan ragam aktivitas keseharian penutur Austronesia memiliki ciri tertentu. Ciri inilah yang akan peneliti data dan kaji dalam kehidupan masyarakat Dayak Meratus. Selain itu, aspek linguistik atau bahasa berupa senarai kosakata Dayak Meratus dan Penutur Austronesia zaman dulu (proto Austronesia) menjadi langkah pembuktian akan adanya hubungan kekerabatan antara dua bahasa ini.

\section{METODE PENELITIAN}

Metode dalam penelitian selain deskriptif kualitatif juga menggunakan kuantitatif. Metode kualitatif digunakan untuk menjelaskan adanya bukti pewarisan budaya Austronesia pada masyarakat Dayak Meratus melalui pengumpulan data yang mendalam. Penelitian kulitatif ini dilakukan dengan langkah kerja mengumpulkan data, mendeskripsikan hasil lapangan untuk yang berkaitan data sosial budaya keseharian. Sugyono (2011:8) bahwa metode kualitatif merupakan metode yang hasil penelitiannya berkenaan dengan interpretatif data.

Berikutnya kuantitatif digunakan dalam hal menghitung hubungan kekerabatan untuk kosakata yang diperbandingkan dengan metode leksikostatistik dalam kajian Linguistik Historis Komparatif . La Ino (2015:1) menyatakan bahwa Linguistik Historis Komparatif sebagai salah satu cabang linguistik mempunyai tugas utama, antara lain menetapkan fakta dan tingkat keeratan dan kekerabatan antarbahasa yang berkaitan erat dengan pengelompokan bahasa-bahasa sekerabat. Selanjutnya untuk metode leksikostatistik akan dioperasionalkan dengan prosedur kerja sebagai berikut.

1. Melaksanakan pengumpulan data.

2. Menyusun transkipsi data

3. Mengadakan penyuntingan data.

4. Menyusun identifikasi dan klasifikasi data. 
5. Menentukan bentuk dan tingkat kekerabatan bahasa Indonesia dengan bahasa Banjar.

Dengan langkah kerja leksikostatistik akan diperbandingkan bahasa Dayak Bukit dan bahasa Austronesia zaman Dulu (bahasa proto). Struktur bahasa yang diperbandingkan yaitu dari segi persamaan dan kemiripan bunyi dalam kosakata dua bahasa tersebut. Berikutnya akan dihitung jumlah kosakata yang berkerabat ini. Azhar (2010: 2) menyatakan evolusi suatu bahasa dapat dilacak dengan cara membandingkan bentuk terkini bahasa tersebut dengan proto bahasanya, yaitu dengan cara mengamati perubahan pada aspek yang paling sensitif untuk berubah yaitu pada tataran fonologisnya. Kosakata yang diperbandingkan dalam penelitian ini merupakan kosakata budaya dasar suku Dayak Meratus yang digunakan sehari-hari.Kosa kata tersebut memiliki makna dan fungsi sosial budaya dalam kehidupan mereka. Sehubungan dengan ini, penelitian yang dilakukan tidak hanya mengkaji unsur bahasa semata akan tetapi berkaitan pula dengan makna dan fungsi unsur bahasa yang didata. Sibarani (2015: 2) menyatakan bahwa antropolinguistik tidak hanya mengkaji masalah unsur bahasa saja tetapi juga mengenai aspek sosial budaya di balik bahasa tersebut.

Berikutnya metode deskriptif dan kuantitatif ini dilakukan melalui tiga teknik pengumpulan data yang digunakan dalam penelitian ini, yakni wawancara, perekaman dan studi dokumentasi.

1. Wawancara

Peneliti mengadakan wawancara dengan informan untuk memperoleh data sosial budaya dan kebahasaan (kosakata) Bahasa Dayak Meratus. Informasi tentang sosial budaya ini diperoleh dari para informan yang berasal dari masyarakat Dayak Meratus Kecamatan Hampang yang diperoleh secara acak. Adapun untuk memperoleh kosakata terutama data yang berhubungan dengan permasalahan yang ada berdasarkan daftara Swadesh yang berjumlah 200 buah. Kosakata ini mencerminkan identifikasi Bahasa Dayak Meratus yang digunakan dalam kehidupan sehari-hari. Wawancara kepada informan atau responden dilakukan penulis dengan syarat yaitu sebagai berikut: (a) 
Informan adalah suku Dayak Meratus; (b) Informan berusia minimal 25 tahun, (c) Informan berdomisili di Kalsel dan jarang meninggalkan desanya atau daerahnya selama lima tahun, (d) informan menguasai Bahasa Dayak Meratus (e) sehat jasmani dan rohani.

\section{Perekaman}

Untuk memperoleh data yang diharapkan sesuai dengan tujuan penelitian dilakukan perekaman terhadap aktivitas keseharian dan penggunaan bahasa penutur asli di lapangan.

\section{Studi Dokumentasi}

Untuk menambah pemahaman penulis terhadap data yang telah diperoleh, digunakan pula dokumentasi berupa surat kabar atau naskah tertulis lainnya yang berkaitan dengan masyarakat Dayak Meratus Kecamatan Hampang dan Penutur Austronesia masa lampau. Selain itu sumber tertulis lainnya yaitu 200 KKDS Austronesia. Sementara itu, untuk senarai kosakata budaya penutur Austronesia berasal dari buku Wurm, S. A \& Wilson, B. 1976. English Finderlist of Reconstrauctions in Austronesian Language.

Berikutnya adalah teknik analisis data. Dari data yang diperoleh dari lapangan di analisis berdasarkan teori dan permasalahan yang ada untuk menentukan adanya pewarisan sosial budaya dan bahasa dari Proto Austronesia pada masyarakat Dayak Meratus Kecamatan Hampang .Analisis data kualitatif dilihat berdasarkan budaya keseharian masyarakat Hampang, seperti bentuk hunian, cara pemenuhan hidup, pakaian, asesoris, dan lain-lain. Budaya keseharian ini disandingkan dengan budaya Autronesia terdahulu.

Khusus untuk perhitungan kuantitatif, sebelum menentukan bukti ada tidaknya pewarisan bahasa tersebut, dilakukan perhitungan leksikostatistik dengan memperhatikan pedoman berikut

a. Mengeluarkan glos yang tidak akan diperhitungkan dalam penetapan kata yang berkerabat (kata kosong) 
b. Menetapkan kata kerabat berupa kata identik yaitu kata yang sama makna dan formatifnya; kata yang memiliki korespondensi bunyi dan kata yang mirip bentuknya

c. Membuat persentase kata berkerabat.

Pada tahap penghitungan terhadap senarai kosakata ini yaitu dengan cara jumlah kata dasar berkerabat dibagi dengan jumlah kosakata yang diperbandingkan kemudian dikali seratus persen sehingga diperoleh persentase jumlah kata yang berkerabat. Hasil persentase ini dimasukan dalam kategori relasi kekerabatan satu bahasa, keluarga, rumpun, mikrofilum, dan mesofilum.

Terakhir, data penelitian adalah masyarakat Dayak Meratus Kecamatan Hampang, Kabupaten Kotabaru. Daerah yang dijadikan pengamatan meliputi desa Hampang, Paramasan 2x9, dan Muara Urie. Ketiga desa ini jauh dari perkotaan. Jarak antara desa dengan kota lebih dari seratus kilo meter. Bahasa yang digunakan ketiga desa adalah Dayak Meratus. Waktu pengambilan data bulan Desember 2018 sampai dengan Februari 2019.

\section{HASIL DAN PEMBAHASAN}

A. Gambaran Masyarakat Dayak Meratus Kecamatan Hampang

Berdasarkan hasil pengamatan di lapangan diketahui secara umum pewarisan jejak budaya penutur Austronesia masih tersisa dalam kehidupan keseharian masyarakat Dayak Meratus Kecamatan Hampang. Hal ini dapat dilihat pada peralatan hidup, rumah, sistem religi, sistem mata pencaharian, dan lain-lain. Berikut gambaran umumnya.

\section{Peralatan Hidup}

Terdapat beberapa peralatan hidup yang bersifat tradisonal banyak ditemukan kala peneliti berada di Kecamatan Hampang ini. Peralatan hidup tersebut antara lain anyaman yang terbuat dari rotan, bamban, nipah, dan 
bambu. Ragam anyaman ini digunakan untuk memudahkan mereka kala melakukan aktivitas keseharian

Anyaman sejenis bakul ini terbuat dari rotan. Motif anyaman berbetuk ukiran sulur-suluran dengan warna ungu. Di sisi kiri kanannya dibuat sebuah tali selempang kecil yang juga terbuat dari rotan. Fungsi benda ini sebagai wadah untuk memuat sayur hasil ladang atau hasil tangkapan ikan dari sungai.

Selanjutnya, pada data yang ditemukan (gambar 2) terdiri atas peralatan hidup masyarakat Dayak Meratus . Peralatan tersebut digantung di dinding ruang dapur. Peralatan yang dimaksud meliputi anyaman (a). tangguk. (b) tanggui. $\quad$ (c) balihum " sejenis bakul biasa ". Anyaman tangguk terbuat dari bambu atau rotan. Dianyam dalam bentuk jaring berbingkai setengah lingkaran. Tangguk tidak diberi warna atau motif apapun. Fungsi tangguk untuk menangkap ikan di sawah, dengan cara memasukan benda tersebut ke dalam sawah yang berair dan berlumpur lalu diangkat. Sementara itu, Anyaman tanggui terbuat dari daun nipah. Bentuknya kerucut setengah lingkaran. Fungsi tanggui sebagai topi pelindung kepala dari sengatan matahari kala bekerja di ladang, kebun, atau sawah._Berikutnya, anyaman balihum_ sejenis bakul biasa digunakan membawa sayur mayur hasil kebun beras.

Peralatan hidup lainnya yang ditemukan adalah lampit, nyiru, dan tempayan, serta kendi. Lampit adalah anyaman yang terbuat dari rotan. Fungsinya sebagai alas di lantai seperti tikar. Saat peneliti berada di salah satu rumah warga, lampit digunakan sebagai alas yang diletakkan di ruang tamu, sementara di atasnya terlihat ada batal, guling, dan ayunan anak kecil .

Berikutnya nyiru atau hampi . Benda ini terbuat dari anyaman bambu berbentuk bundar berbingkai. Fungsinya untuk menampi beras agar bersih dari antah. Tempayan, tajau, dan kendi terbuat dari tanah liat yang dibuat oleh pengrajin. Tempayan berbentuk bulat besar untuk tempat beras . Tajau untuk menyimpan air dengan jumlah besar yang diletakan di bagian ruang 
belakang rumah . Sementara kendi untuk wadah air minum yang ada di atas meja.

Peralatan lainnya adalah rahap atau jala. Alat ini digunakan untuk menangkap ikan di air yang deras. Kail atau unjun lengkap dengan mata kailnya yang terbuat dari bilah bambu kecil juga menjadi salah satu peralatan mencari ikan bagi masyarakat Dayak Meratus di Kecamatan Hampang. Berikutnya adalah butah atau ungking. Alat ini sejenis bakul yang dibawa di punggung. Fungsinya membawa peralatan seperti parang, ranggaman atau ani-ani, tatujah atau alu untuk melobangi tanah, dan lain-lain.

Jejak Austronesia berdasarkan data non-linguistik sebagaimana telah dipaparkan sebelumnya menunjukkan adanya bukti masih terdapat jejak budaya Austronsia pada masyarakat Dayak Meratus Kecamatan Hampang. Hal ini dapat dilhat secara garis besar masyarakat Dayak Meratus Kecamatan Hampang memiliki budaya bertanam padi, memiliki alat memotong padi bernama ani-ani, rumah panggung, tajau (tempat air yang terbuat dari tanah), memelihara ayam, sebagian memelihara anjing, dan kerbau, menggunakan kerbau atau sapi untuk upacara, rumahnya ditopang pasak kayu, mengenal asesoris seperti gelang, dam pemimpinnya ada yang diangkat karena faktor keturunan. Apa yang disebutkan ini senada dengan apa yang dikemukan oleh pendapat sebelumnya yang menyatakan aktivitas budaya masyarakat penutur Austronesia di masa silam. Prasetyo (2016:182) menyatakan bahwa kehidupan penutur Austronesia dapat dicirikan seperti bercocok tanam padi, ani-ani, membuat tembikar, berumah panggung dengan denah segiempat,mengayau, membuat minuman dari beras, domestikasi babi,dan kerbau untuk upacara, mendirikan megalitik, dan memperkenalkan perahu cadik. Demikian pula Suroto (2016:122) menyatakan kebudayaan Austronesia mengenal domistikasi ayam, anjing, dan babi. Peralatan yang mereka kenal adalah manik-manik, mata kail, gelang tangan, dan terompet. Organisasi kemasyarakatan terstruktur dalam sistem hierarki, para pemimpinnya dijabat secara turun temurun. 


\section{Hunian}

Hunian dengan lingkungan yang ada di sekitar desa menggambarkan adanya dua pola pemukiman, yaitu pertama, pola memusat dan kedua, menyebar. Adapun jarak antar-rumah penduduk ada sekitar lima sampai 10 meter, namun ada pula yang dibatasi oleh kebun dan semak belukar. Meskipun rumah hunian masyarakat ini ada yang modern karena menggunakan material batu gunung dan semen, namun masih banyak pula yang masih berbentuk rumah tradisional. Bangunan tradisional di pedesaan yang dimaksud meliputi kantor pemerintah (KUA), rumah penduduk biasa dan balai adat bahkan untuk pondok di ladang atau rungku, dan poskamling. Pada umumnya semua merupakan rumah panggung. Rumah panggung yang dibuat tidaklah setinggi rumah Banjar tradisional zaman dulu yang dihuni oleh kalangan saudagar dan bangsawan.

Berdasarkan data di lapangan, bangunan tradisional menggunakan bahan dasar kayu. Bagian bawahnya menggunakan penopang tongkat kayu dengan tinggi kurang lebih setengah meter. Bagian atas atau bungan juga menggunakan kasau kayu. Bagian atap memiliki konstruksi yang meninggi. Bahan atap ini beragam, ada berasal dari daun pohon sagu, dari seng, atau dari sirap yang dibuat dari kayu ulin. Sementara bagian dindingnya ada yang menggunakan kayu ulin, kayu hutan, dan ada berdinding anyaman bambu atau balatai.

Khusus rumah hunian yang digunakan sehari-hari, terdiri atas empat bagian. Antar bagian dibatasi oleh dinding dan di topang oleh batangan kayu. Bagian depan disebut dengan beranda atau karbil. Sebagian masyarakat Dayak Meratus memfungsikan beranda selain untuk duduk-duduk melepas lelah atau bercengkrama dengan keluarga dan tetangga, juga untuk meletakan kendaraan atau sepeda. Selain itu, beranda juga digunakan untuk menumpuk sementara hasil panen yang bisa bertahan lama, seperti padi setelah selesai dijemur dan literan jagung selesai dikeringkan.

Bagian dalam rumah terdiri atas ruang muka atau atau ruang tamu, ruang tengah, kamar tidur atau pindalam . Ruang tamu ini ada yang 
difungsikan untuk menerima tamu ada juga tempat meletakan kendaraan dan hasil panen. Sementara ruang tengah digunakan untuk tempat bersantai. Karena itu tidak mengherankan pada umumnya, di ruangan bagian tengah ini terdapat televisi, ayunan bayi, dan alat pengeras suara atau speeker/sound.

Bagian rumah selanjutnya dapur atau dapuran atau padangan. Dapur untuk meletakkan tempat memasak dan berbagai peralatan untuk berburu dan berladang, termasuk menyimpan sebagian hasil panen, seperti padi dan jagung kering. Adapun, bagian paling ujung rumah disebut dengan undangan. Bagian ujung rumah ini memiliki fungsi sebagai tempat untuk mencuci pakaian, beras, dan piring, termasuk di dalamnya terdapat WC.

Rumah penutur Austronesia dibuat model panggung dengan ditopang pasak-pasak kayu. Hal ini untuk menghindari banjir, hewan buas sehingga aman di lingkungan terbuka yang saat itu masih liar Khusna (2015:23). Sehubungan dengan pendapat ini, rumah Dayak Meratus berbentuk panggung. Khusna (2015:6) menyebutkan ciri kehidupan budaya Austronesia yang ditemukan adalah adanya pasak-pasak kayu sebagai bagian rumah panggung dan bentuk hunian bertipe segiempat

Sehubungan dengan data yang diperoleh di lapangan, meskipun banyak rumah berbentuk panggung, namun masyarakat Dayak Meratus sekarang dalam membuat konstruksi rumah hunian tersebut sudah tidak terlalu tinggi lagi. Hal ini disesuaikan dengan kondisi alam yang tidak begitu liar dan tidak banjir. Di samping itu, kalau dahulu, bentuk rumah minimalis jumlah ruangnya, namun sekarang berbeda karena disesuaikan dengan fungsi sekarang yang membedakan antara ruangan tamu, ruang kamar tidur, ruang dapur, dan ruang untuk mencuci, termasuk ruangan yang memungkinkan untuk menyimpan hasil panen dan peralatan hidup lainnya. Akan tetapi untuk tempat tinggal yang berada di tengah area kebun atau huma yang jauh dari pemukiman, bentuk rumah panggung dengan jumlah ruang minimalis tetap dipertahankan meskipun dengan ketinggian bagian bawah sekitar satu atau setengah meter dari lantai dasar, dengan pasak kayu, dan berkonstruksi segi empat . Di satu ruangan itulah penghuninya melakukan aktivitas tidur, makan, 
ganti pakaian dan duduk bersantai. Bahkan kemungkinan juga, untuk jenis rumah di tengah huma yang cukup besar maka memungkinkan di dalamnya menyimpan hasil panen baik padi maupun jagung, dan lain sebagainya.

\section{Pemenuhan Kebutuhan Hidup}

Beragam aktivitas yang dilakukan oleh masyarakat Dayak Meratus Kecamatan Hampang untuk memenuhi kebutuhan sehari-hari. Aktivitas yang dimaksud meliputi berburu, berladang, bertani, dan mencari ikan, serta jual beli, termasuk mendulang. Aktivitas tersebut mereka lakukan dalam dan antardesa, di tengah alam Bukit Meratus yang masih menyediakan sumber daya hayati dan hewaninya.

Salah satu cara mereka berburu_hewan seperti kijang, burung, dan babi adalah dengan membuat jebakan tertentu. Sebutan lain dari berburu dalam bahasa Dayak Meratus adalah bagarit. Hasil buruan seperti pipit atau putung, rusa atau menjangan, dan babi dapat dipelihara, dikonsumsi sendiri atau dijual. Selain berburu aktivitas lainnya adalah mencari ikan di sungai dengan segala peralatannya. Ikan yang mereka kenal dalam kehidupan sehari-hari seperti lele atau aliraw, gabus atau haruan, papuyu, ikan mas, ikan nila, ikan lais, dan lainnya.

Suku Dayak Meratus di Hampang dalam keseharian melakukan aktivitas berladang (Hartatik 2015; 102). Berdasarkan pendapat ini, apa yang dikatakan tersebut telah dibuktikan sendiri oleh peneliti. Baladang, bahuma atau bertani merupakan aktivitas utama masyarakat ini. Manugal adalah cara bertani di tanah kering, khusus di daerah pebukitan atau dataran tinggi. Hasil dari padi ini dikenal dengan aromanya yang berbau pandan. Setiap tahun masyarakat Dayak Meratus Kecamatan Hampang akan melakukan upacara manyanggar dalam rangka tanda syukur atas keberhasilan panen yang telah mereka terima. Hewan yang mereka gunakan dalam upacara ini adalah hewan kerbau atau sapi.

Pada saat peneliti berada di kecamatan Hampang, saat itu penduduk sedang giat melakukan aktivitas berkebun jagung. Sebelumnya mereka giat 
berkebun sawit dan karet. Hasil kebun lainnya yang menghasilkan adalah cabe dan labu putih. Berdasarkan pengamatan peneliti. Di pekarangan penduduk banyak hamparan padi yang dijemur dengan menggunakan tikar yang terbuat dari anyaman pandan. Di samping itu, hampir di setiap pekarangan rumah terdapat wadah untuk menjemur jagung. Wadah ini berbentuk persegi empat panjang yang terbuat dari kayu dan bambu

Hasil kebun lainnya adalah pisang, kelapa, nangka, nangka Belanda, rambutan, belimbing, jahe atau lahiya, kunyit, dan palawija. Sementara tumbuhan liar yang banyak tumbuh di kebun mereka meliputidurian, asamasaman, kesturi, manggis, gandaria, duku, pampakin, dan lain-lain.

Selanjutnya, berdasarkan data di lapangan. Banyak penduduk Dayak Meratus Kecamatan Hampang yang memelihara ayam dan sebagian kecil memelihara anjing, namun untuk babi tidak terlihat. Pemeliharaan anjing tidak dilakukan secara khusus, hewan ini dibiarkan berkeliaran begitu saja. Namun khusus ayam, dibuatkan kandangnya yang berbentuk panggung. Kandang ayam ini dibuat dari kayu dan di letakkan di belakang pekarangan atau depan rumah.

Selanjutnya, dari keterangan beberapa orang penduduk menceritakan bahwa sebagian penduduk menghasilkan minyak kelapa dengan cara sendiri. elapa yang tua dibuang kulitnya baik di kupas dengan parang maupun dihuak. Setelah itu, kelapa dibelah lalu diambil dagingnya. Daging kelapa ini diparut kemudian diperas. Air perasan ini direbus sampai menghasilkan minyak kelapa.

Kemampuan masyarakat Dayak Meratus Kecamatan Hampang dalam memenuhi kebutuhan hidup sehari-hari ini secara mandiri juga dapat peneliti dengar dari salah seorang informan. Menurutnya, jika ingin gula merah, maka cukup naik pohon aren kemudian letakan satu atau dua buah bambu yang kosong. Cairan yang keluar dari bunga aren akan masuk ke dalam bambu tersebut. Kemudian air yang disebut nira ini direbus lalu masukan ke dalam tempurung kelapa berbentuk setengah lingkaran, setelah itu dinginkan, maka 
jadilah gula aren. Air aren yang menghasilkan nira ini juga dapat diolah oleh masyarakat menjadi tuak dengan proses fermentasi .

Cara pemenuhan kebutuhan hidup lainnya adalah dengan memanfaatkan tanaman sekitar. Tumbuhan yang terdapat di kebun penduduk meliputi kelapa atau nyiur, tebu, bambu , mentimun, pisang, talas , kunyit, dan pandan. Kunyit atau janar misalnya digunakan untuk mengobati memar dan bengkak. Caranya, kunyit diparut lalu masukan sedikit minyak dan garam kemudian dipepes. Masukan ramuan tadi dalam kain, lekatkan ke bagian yang memar dan bengkak. Selain kunyit, jenis tanaman sirih juga dapat digunakan untuk mereka yang selesai melahirkan. Sirih direbus, lalu diminum. Sirih juga digunakan oleh sebagian kecil penduduk desa yang berusia lanjut untuk menginang. Fungsi menginang agar gigi menjadi kuat.

Berikutnya, untuk menambah ragam menu makanan sehari-hari, masyarakat ini mengonsumsi rebusan pucuk daun singkong, kacang panjang, umbut rotan, dan beragam jenis jamur. Jamur ini ada yang tumbuh di sela akar kelapa dan ada yang tumbuh di sela akar sawit. Biasanya jamur tersebut dioseng kering atau diberi sedikit air dengan bumbu bawang merah, bawang putih, tambah cabe, sedikit gula dan garam. Menurut mereka, rasa jamur ini kala sudah diolah seperti daging ayam oseng. Ose

Cara memenuhi kebutuhan hidup masyarakat Dayak Meratus ini yaitu berjual beli di pasar. Pasar besar yang sering mereka kunjungi bernama Malangkayam. Menurut penuturan mereka, pasar ini merupakan pusat perdagangan antardesa. Dalam kegiatan jual beli ini dominan menggunakan uang sebagai sarana tukarnya, bukan barter seperti zaman dulu. Di pasar inilah masyarakat Dayak Meratus maupun pendatang seperti Bugis, NTT, dan masyarakat Jawa turut meramaikan jual beli di tempat tersebut.

Berdasarkan aktivitas dan benda-benda pendukung masyarakat Meratus ini telah menunjukkan adanya pewarisan khas yang kemungkinan besar berasal dari Autronesia adalah kepandaian masyarakat Dayak Meratus dalam membuat air beralkohol dari air aren atau laang. Di samping itu, masyarakat Dayak Meratus ini memanfaatkan daun sirih untuk pengobatan 
atau kesehatan. Daun sirih juga digunakan untuk menginang. Hal ini sesuai dengan Suroto (2010:55) yang menyatakan bahwa beberapa pendapat dari para ahli menyebutkan ciri khas budaya Austronesia meliputi mengunyah sirih, membuat tato, rumah panggung, pembuatan minuman beralkohol dari aren. Demikian pula dengan pendapat Wiradyana (2016:258) yang menyebutkan bahwa menyebutkan mengunyah sirih-pinang model aktivitas terkait masyarakat Austronesia.

Sementara hewan di sekitarnya baik yang dipelihara atau tidak, meliputi, babi, anjing, tikus, ayam, dan laba-laba. Data ini menunjukkan adanya kesesuaian dengan apa yang yang dinyatakan oleh Kern dalam (muljana, 2017:12) yang menyebutkan nama mahluk hidup seperti babi, anjing, dan laba-laba menjadi bagian dari hewan-hewan yang ada pada kehidupan sehari-hari Penutur Austronesia.

\section{Kepercayaan}

Kepercayaan Kaharingan masih bertahan pada masyarakat ini. Selanjutnya, masyarakat Dayak Meratus Kecamatan Hampang mempercayai akan nenek moyang. Hal ini dapat dilihat pada cerita tentang leluhur mereka yang bernama Dayuhan dan Bambang Suara. Cerita ini dituturkan oleh beberapa orang informan. Menurut kepercayaan Dayak Meratus, nenek moyang mereka tersebut masih memperhatikan kehidupan di dunia hingga sekarang.

Kepercayaan akan benda-benda tertentu juga menjadi bagian religi. Salah satu kepercayaan mereka adalah adanya perlindungan yang bisa dilakukan oleh sisik tenggiling. Tidak mengherankan sebagian rumah di masyarakat ini menyimpan sisik tersebut, sebab menurut kepercayaan tradisional, sisik trenggiling dapat mencegah kebakaran rumah. Sehubungan dengan adanya pewarisan kepercayaan, Simanjuntak (2015:39) menyatakan bahwa Sistem kepercayaan merupakan unsur budaya yang paling sulit berubah, hingga umumya masih bertahan pada suku-suku tradisional tertentu, seperti kaharingan pada Suku Dayak di Kalimantan 


\section{B. Gambaran Bahasa Masyarakat Dayak Meratus}

Berdasarkan data di lapangan, di peroleh senarai 200 kosakata dasar bahasa masyarakat Dayak di kecamatan ini dengan kosakata Penutur Austronesia. Kosakata ini memiliki perbedaan, kemiripan, dan persamaan antar kedua penutur. Contoh 10 kosakata diantaranya dapat dilihat pada tabel 1 dan 2 berikut ini.

Tabel 1. Contoh 10 Buah Kosakata Dasar Bahasa Masyarakat Dayak Di Kecamatan Hampang Yang Berbeda Dengan Kosakata Penutur Austronesia (PAN)

\begin{tabular}{|l|l|l|l|}
\hline No & $\begin{array}{l}\text { Bahasa } \\
\text { Indonesia }\end{array}$ & $\begin{array}{l}\text { Kosakata Dayak Meratus } \\
\text { Kecamatan Hampang }\end{array}$ & $\begin{array}{l}\text { Kosakata yang berasal dari } \\
\text { penutur Austronesia }\end{array}$ \\
\hline 1. & air & Aying & Danum \\
\hline 2. & bagaimana & kaya apa & Aua \\
\hline 3. & baik & Baik & mapia \\
\hline 4. & bakar & Bakar & tutuG \\
\hline 5. & baring & Gurig & Inep \\
\hline 6. & baru & Puga & Baeru \\
\hline 7. & basah & Musi & Basa \\
\hline 8. & beri & Bari & Lakad \\
\hline 9. & besar & Ganal & Raya \\
\hline 10. & bunga & Kambag & buGa \\
\hline
\end{tabular}

Tabel 2. Contoh 10 Kosakata Swades Bahasa Masyarakat Dayak Di Kecamatan Hampang Yang Mirip Dan Sama Dengan Kosakata Austronesia (PAN)

\begin{tabular}{|l|l|l|l|}
\hline No & \multicolumn{1}{|c|}{$\begin{array}{c}\text { Bahasa } \\
\text { Indonesia }\end{array}$} & \multicolumn{1}{|c|}{$\begin{array}{c}\text { Kosakata Dayak } \\
\text { Meratus Kecamatan } \\
\text { Hampang }\end{array}$} & $\begin{array}{c}\text { Kosakata yang berasal } \\
\text { dari Penutur } \\
\text { Austronesia }\end{array}$ \\
\hline 1 & Abu & habu & abu \\
\hline 2 & akar & akar & akar,wakar \\
\hline 3 & Alir (me) & magalir & alir \\
\hline 4 & anak & anak & anak \\
\hline 5 & angin & agin & agin \\
\hline 6 & apa & apa & apa \\
\hline 7 & api & api & sapuy \\
\hline 8 & ayah & ipag & bapak \\
\hline 9 & batu & batu & batu \\
\hline 10 & belah & balah & bela \\
\hline
\end{tabular}

Berdasarkan dua tabel ini dapat diketahui bahwa Penutur bahasa Dayak Meratus Kecamatan Hampang dalam kehidupan sehari-harinya menggunakan kosakata yang sama, mirip, dan ada yang berbeda dengan Penutur Austronesia masa silam. Berdasarkan perhitungan leksikostatistik 
dalam kajian linguistik historis komparatif, dapat dikatakan bahwa kedua bahasa ini memiliki hubungan kekerabatan. Hal ini dapat dilihat pada 67 kosakata bahasa Dayak Meratus yang memiliki kemiripan dan persamaan dengan bahasa Penutur Austronesia (PAN).

Berdasarkan kosakata yang dimiliki oleh masyarakat Dayak Meratus, dari hasil perhitungan leksikostatistik yang terdapat dalam kajian linguistik historis komparatif ini dapat dihitung sebagai berikut. Dua ratus kosakata Swades yang memiliki kemiripan dan persamaan antara bahasa Dayak Meratus Kecamatan Hampang dengan Penutur Austronesia ini berjumlah enam puluh tujuh buah. Keenam puluh tujuh ini memiliki korespondensi bunyi dan korespondensi leksikal sebagaimana diuraikan sebelumnya. Keenam puluh tujuh kosakata ini dibagi dengan seratus tiga puluh delapan buah kosakata yang disenaraikan dengan kosakata Austronesia, selanjutnya hasilnya dikali dengan seratus. Jumlah yang diperoleh sebesar 48,5\%. Jumlah 48,5\% ini dihubungkan dengan kategori tingkat kekerabatan bahasa termasuk dalam tingkat keluarga bahasa. Aatau dengan kata lain bahasa Dayak Meratus Kecamatan Hampang memiliki unsur pewarisan dari bahasa Proto Austronesia sebesar 48. 5\%. Hubungan kekerabatan bahasa Dayak Meratus Kecamatan Hampang, Kabupaten Kotabaru ini termasuk dalam keluarga bahasa Proto Austronesia.

Hasil perhitungan yang menunjukan adanya hubungan kekerabatan bahasa Masyarakat Dayak Meratus Kabupaten Kotabaru Kecamatan Hampang sebagaimana telah diuraikan sebelumnya, ternyata hal ini lebih dipertegas lagi melalui uraian deskripsi yang berwujud adanya kosakata kedua penutur yang mirip dan sama, atau memiliki korespondensi fonemis karena terdapat pola bunyi yang bersistem dalam kedua penutur bahasa (walau tidak semua). Pola perubahan bunyi yang bersistem ini dalam ilmu linguistik historis komparatif disebut dengan korespondensi bunyi.Adanya korespondensi ini menurut kajian linguistik menjadi salah satu bukti adanya pewarisan bahasa sekarang dari bahasa Protoaustronesia terdahulu. Contohnya adalah sebagai berikut. 


\section{a. $\quad$ PAN *[a] $>[\mathrm{a}]$}

Maksudnya adalah terjadinya pola bunyi untuk vokal a pada PAN terhadap bahasa Dayak Meratus Kecamatan Hampang Kotabaru. Pola bunyi yang dimaksud yaitu, vokal a pada kosakata Dayak Meratus tidak berubah sebagaimana bunyi vokal a pada PAN. Contohnya vokal *a pada kosakata abu, akar, garuk, dasun, abu dan huzan dalam PAN menjadi tetap vokal a pada kosakata habu, akar, garu, dawun, dan hujan pada bahasa Dayak Meratus Kecamatan Hampang.

\section{b. $\quad$ PAN *[e] $>[\mathrm{a}]$}

Maksudnya adalah vokal *a pada PAN tidak mengalami perubahan pada kosakata Dayak Meratus. Bunyi vokal *e pada PAN mengalami perubahan menjadi a dan i dalam kosakata Dayak Meratus ini. Contoh kosakata yang vokal e mengalami perubahan menjadi a ini yaitu kosakata PAN bele, dare,_dalem, denger, dan xepat menjadi balah, darah, dalam, danger, dan ampat pada kosakata Dayak Meratus.

\section{c. $\quad$ PAN *[b]>[b]}

Maksudnya adalah bunyi konsonan *b pada PAN dominan tidak mengalami perubahan pada kosakata Dayak Meratus. Hal ini dapat dilihat pada tabel 2. Contohnya yaitu konsonan b dalam kosakata PAN bener, abu, bariw, bela, dan bitu'en tetap menjadi konsonan b dalam kosakata Dayak Maratus Kecamatan Hampang, yaitu bujur, habu, buruk, balah, dan bintang.

Di samping terdapat korespondensi bunyi, berdasarkan dua tabel ini terdapat juga korespondensi leksikon. Korespondensi yang dimaksud ini yaitu terdapatnya persamaan bentuk dan makna dalam kedua kosakata penutur. Hasil pendengaran langsung yang menjadi data tertulis yang peneliti peroleh ini semakin memperkuat adanya asumsi jejak pewarisan Austronesia terdapat dalam bahasa Dayak Meratus Kecamatan Hampang 


\section{PENUTUP}

Wujud jejak penutur Autronesia masa silam pada masyarakat Dayak Meratus Kecamatan Hampang ini dibuktikan dengan unsur nonlinguistik dan linguistik. Unsur nonlinguistik meliputi peralatan hidup, hunian, pemenuhan kebutuhan hidup, pakaian asesoris, dan kepercayaan. Sementara untuk unsur linguistik dapat ditemukan dalam senarai 138 kosakata bahasa Dayak Meratus dengan Proto Austronesia.

Kedua unsur ini membuktikan akan adanya pewarisan kehidupan sosial budaya dan bahasa. Kehidupan sosial budaya masyarakat Dayak Meratus Kecamatan Hampang memiliki kemiripan bentuk maupun konsep dengan Austronesia. Sementara itu, dari perbandingan kosakata kedua penutur menggambarkan adanya hubungan kekerabatan sebesar $48 \%$. Atau dengan kata lain bahasa Dayak Meratus Kecamatan Hampang, Kabupaten Kotabaru berada dalam kategori keluarga bahasa dengan Proto Austronesia. Adanya hubungan kehidupan antara masa silam dengan masa sekarang dalam sebuah masyarakat dapat dibuktikan tidak hanya melaui artefak kuno. Akan tetapi dari segi unsur sosial budaya dan bahasa menjadi sarana pembuktian juga. Hasil penelitian ini dapat menjadi materi pendukung yang memperkuat pendapat akan adanya hubungan kekerabatan antara Penutur Austronesia dengan masyarakat Dayak Meratus di Kecamatan Hampang. 


\section{DAFTAR PUSTAKA}

Azhar, Iqbal Nuru. 2010. Jejak Protobahasa Austronesia pada Bahasa Madura. Dalam Jurnal Metalingua 8 (2). Hlm. 1- 8.Balai Bahasa Jawa Barat.

Faidi, Ahmad. 2015. Suku Dayak. Makasar: Arus Timur.

Hartatik. 2014. Religi dan Peralatan Tradisional Suku Dayak Meratus di Kabupaten Balangan, Kalimantan Selatan. Berita Penelitian Arkeologi. Volume 6. Hlm. 57-101. Banjarbaru: Balai Arkeologi Banjarmasin.

Hartatik. 2014. Perbandingan Bahasa dan Data Arkeologi pada Suku Tidung dan Dayak Di Wilayah Nunukan: data Bantu untuk Rekonstruksi Sejarah dan Perubahan Budaya. Jurnal Naditira Widya. 8 (2). Hlm. 29-48. Banjarbaru: Balai Arkeologi Banjarmasin.

Hartatik. 2015. Religi dan Peralatan Tradisional Suku Dayak Meratus di Kotabaru, Kalimantan Selatan. Dalam Jurnal Kindai Entam. 1(1). Hlm. 95-120). Banjarbaru: Balai Arkeologi Banjarmasin.

Info Kotabaru. 2019. Diakses 15 Februari 2019 dari http://www. bappedakotabaru. info/umum/37/.

Khusna, A. A. 2015. Migrasi Austronesia di Asia Tenggara. Makalah. Yogyakarta. Universitas Gadjah Mada.

La Ino. 2015. Pemanfaatan Linguistik Historis Komparatif dalam Pemetaan Bahasa-Bahasa Nusantara. Dalam Jurnal Retorika. 1(2). Hlm. 351365: Program Pascasarjana Universitas Warmadewa Program Studi Magister Linguistik

Prasetyo, Bagyo. 2016. Jejak Awal Penutur Austronesia di Kepulauan Nusantara : Sudut Pandang Lingkungan, Manusia, dan Budaya. dalam Bunga Rampai Jejak Austronesia di Indonesia. Hlm. 172-195. Yogyakarta: Gadjah Mada University Press.

Sibarani, Robert. 2015. Pendekatan Antropolinguistik Terhadap Kajian Tradisi. Dalam Jurnal Retorika. 1 (1). Hlm. 1- 17. Program Pascasarjana Universitas Warmadewa Program Studi Magister Linguistik 
Sugianto, Bambang. 2014. "Kajian Awal tentang Lukisan Dinding Gua di Liang Bangkai, Kalimantan Selatan”. Dalam Jurnal Naditira Widya. 8 (2). Hlm. 59-68. Banjarbaru: Balai Arkeologi Banjarmasin.

Sugianto, Bambang. 2015. Jejak Kolonisasi Prasejarah di Pegunungan Meratus. Bunga Rampai Hasil Penelitian Arkeologi. Hlm. 2. no-. Banjarbaru: Balai Arkeologi Banjarmasin.

Sugiyono. 2011. Metode Penelitian Kuantitatif, Kualitatif dan R\&D. Bandung: Afabeta.

Sunarningsih. 2015. DAS Barito dan Jejak Kehidupan Masa Proto Sejarah. Bunga Rampai Hasil Penelitian Arkeologi. Hlm. 2. no-. Banjarbaru: Balai Arkeologi Banjarmasin.

Suroto, Hari. 2016. "Budaya Austronesia di Kawasan Danau Sentani". Dalam Jurnal Papua, 8(2). Hlm. 121-128. Balai Arkeologi Papua.

Wurm, S. A \& Wilson, B. 1976. English Finderlist of Reconstrauctions in Austronesian Language. Departement of Linguistics, Research School of Pacific Studies. The Australian National. 